ANNA SLATINSKÁ ${ }^{1}$

\title{
THE IRISH LANGUAGE - A UNIQUE PART OF IRISH LIFE AND CULTURAL REVITALISATION AND PROTECTION
}

\begin{abstract}
The present paper is devoted to the topic of the Irish language and its relation to Irish identity in the modern world, taking into account crucial aspects of the language's revitalisation and protection. The focus is predominantly on particular ways of achieving the ambitious goal of societal bilingualism in Ireland in the long term. The notion that language and identity are interrelated is the leitmotif of this chapter. Approaching the issue from socio-linguistic and ethnographic perspectives, the revitalisation of the Irish language may trigger the interest of the wider public, assuming that language is an invaluable part of spiritual, nonmaterial culture. Indeed, we consider that the death of the Irish language would be a serious loss not only in the sphere of Ireland's cultural and national heritage, but also in the wider European sphere.
\end{abstract}

Key words: Irish language, identity, culture, revitalisation

\section{INTRODUCTION}

The acquisition and use of a minority language is obviously a key element in any language's revitalisation process. One must stress the significant position of the Irish language not only in Irish society, but also in a worldwide perspective, taking into account the added value generated by all languages, not omitting minority and lesser-used languages which create an integral part of the wider European identity.

\footnotetext{
${ }^{1}$ PhD; Univerzita Mateja Bela, Banská Bystrica; anna.slatinska@umb.sk.
} 
The Irish language is part of Irish history and culture. Acknowledging our history enables us to keep the bond with our family or ancestors, simultaneously giving us a sense of unity. Thanks to identification with our roots, we feel a sense of belonging to a wider community. ${ }^{2}$ The Irish language is then viewed as an essential part of the Irish past and cultural heritage of the nation.

This topic of linguistic and ethnic revitalisation is being intensely debated nowadays in all parts of Europe. Certain efforts have recently been made to reverse the process of "the death of language" and thereby prevent the assimilation and/or extinction of the majority of the world's languages. These efforts can be traced in different regions of the world, not only in the European context. On the one hand, we may observe various globalising and unifying tendencies, while, on the other, we may also notice a considerable interest in the preservation and cultivation of specific, localised phenomena connected with minority languages threatened with extinction.

Linguistic and cultural diversity is one of the core elements on which the "European" identity is built. Therefore, we stress the importance of European language policy in terms of the need to protect minority, regional and lesser-used languages. The Irish language is the first national and official language of the Republic of Ireland, whereas the English language is defined as its second official language, according to the Irish Constitution. Although the majority of people in the Republic of Ireland speak only English, Irish (or Irish Gaelic) is arguably one of the most important elements of Irish national and cultural identity, despite its minority position in the public sphere and in daily life.

It is very difficult to measure in a quantitative way the extent to which people value any given language. It is the same with identity. We view a language as a part of its users' identity, and both language and identity evolve in time. These are not static but fluid, undergoing changes in time. Moreover, we approach the topic of language and identity in an interdisciplinary way.

As one assumes that language, culture and identity are interrelated, the loss of any language could have serious consequences for the preservation of an original culture, and vice versa. Although the public is hugely polarised in its views on what would happen if a minority language died

${ }^{2}$ S. Ó Tuama, The Facts About Irish, Baile Atha Cliath: An Chead Chlo (Irish Edition) 1964, p. 48. 
out one day, we must suppose that it is very important to pay attention to the revitalisation of any minority or lesser-used languages in view of the fact that other European languages might face a similar problem at some stage in the future. In the following sections we focus on some aspects of why language and identity are intertwined, and on specific ways of revitalising the Irish language.

\section{THE PRESENT STATE OF AFFAIRS}

One assumes that the more people are exposed to Irish Gaelic through the medium of various Irish-language services and cultural activities, the more viable and vivid their participation in Gaelic ethno-culture will be. As we have found, economic support for the Gaeltacht (Irish-speaking areas, located predominantly in the west of Ireland) plays a crucial role in language revitalisation. In addition to this, attention should be paid to the dissemination of information about the benefits of bilingualism. We also suggest that families should be supported in bringing up their children through the medium of Irish, in view of the fact that they can play a huge role in preserving the language and reversing the language shift. In many Irish-speaking communities there is a tendency to prefer English as the language of communication nowadays. Thus, the role of the family as well as of educational institutions is of utmost importance in the case of the intergenerational transmission of Irish. A successful transfer of language habits depends, however, on a positive attitude and on a more enthusiastic approach to the establishment of the Irish language, or more realistically of bilingual households in view of the fact that monolingual speakers exist no more (with the exception of a tiny percentage of children brought up solely through the medium of Irish).

Currently, the Irish language is being revitalised as a unique cultural element. There are many organisations which support language revitalisation, among them Conradh na Gaelige, Foras na Gaelige, Údarás na Gaeltachta, the National University of Ireland, Galway, and the Irish Language Theatre. All the above-mentioned organisations have the use of the Irish language on their agenda and Irish language revitalisation as one of their key goals.

The Irish language was declared one of the official working languages of the European Union in 2007, generating new working positions for 
prospective translators, interpreters and teachers. The Irish language is a compulsory subject in mainstream schools, as well as being a language of instruction within Irish-language medium schools (gaelscoileanna). Currently, there are many students studying the Irish Language, Irish Studies or Celtic Studies at universities in Ireland and abroad, which is also a sign of interest in the language. Moreover, the language itself has gained popularity and prestige in comparison with an earlier period when it was considered to be of inferior status.

\section{THE METHODOLOGY}

The decision to use any particular language can, in the case of a minority language, be the democratic choice of every individual, simultaneously being an expression of that individual's identity. Language in this context is thus viewed as the very condition of an identity. The interrelation of language and identity can, therefore, be examined from different perspectives (linguistic, sociolinguistic, psychological, and historical).

The aim of this paper is to present the information gathered through the medium of field research carried out in the city of Galway, within the National University of Ireland (abbreviated as NUIG), as well as outside the city, accentuating the cardinal aims and priorities of the officially adopted 20-Year Strategy for the Irish Language 2010-2030 and the Official Languages Act, which came into force in 2003 , on the current state and position of the Irish language in the Republic of Ireland, focusing in a more detailed way on how the language positions itself within the cultural identity of the Irish. Furthermore, we focus on possible techniques for revitalising and protecting the language for future generations. All the data acquired was gained, using the techniques of qualitative research, through the medium of semi-structured interviews, focus group discussions, and direct and indirect observations carried out during our short-term stay in the Republic of Ireland.

The field research aimed to uncover both the real state of the Irish language today and the attitudes of people towards language revitalisation and towards different issues concerning the probability of Irish language survival in the future. 


\section{LANGUAGE AND IDENTITY}

Each language is obviously an invaluable element in terms of national cultural heritage. Language is therefore a significant cultural and social construct. Although language usage can generate feelings of pride, it can also cause the emergence of fear ("the fear factor"), uncertainty and shame, especially in the case of minority or lesser-used languages. These were regarded in the past as inferior languages spoken by backward or rural people in comparison to the dominant language, the language of "progress". Indeed,

Language symbolizes who we are and where we belong, it is a sign of affiliation to an ethnic community (language as an ethno-significant element) although the ideal of one language and one state cannot be realized anymore. ${ }^{3}$

Simultaneously, a language intertwines with the collective awareness (the historical awareness) of a given community. Cultural groups can be defined by language, which is believed to be the key aspect of human capital. People tend to construct their identities through the semiotic character of language, taking into account the communicative and identificational performance of identity following the fundamental categorization principle ("them versus us").

Language is one of the nodal cultural expressions of individuality. It enables the transfer of memories and experience to play a pivotal role for future generations. Language has the power to unite and divide. According to Bilovesky:

Language is a cultural product of man's having the ability to cultivate human beings. Human language develops together with man and the cultural environment in which it exists. Language is very tightly connected with the culture of its bearer. ${ }^{4}$

In addition, language plays a key role in terms of social interaction although this is more difficult with minority, regional and lesser-used languages.

${ }^{3}$ S. Ondrejovič, V. Krupa, My a tí druhí v modernej spoločnosti, Bratislava 2009, p. 113.

${ }^{4}$ V. Biloveský, "Does Integrating Europe Need Polylingualism and Multiculturalism?", European Researcher, vol. 42, no. 2-3 (2012), p. 455. 
Languages reflect the culture and environment of those who use them in everyday communication.

Languages react and adapt to the needs of the culture. Through the medium of language we observe the world. ${ }^{5}$ [re-translation from Czech - AS]

A significant part of culture is reflected in language. Thanks to the use of language, we also come into contact with the culture of the relevant cultural environment.

The studies mentioned above include frequent references to the fact of language acting as a determinant of social stature in terms of social class. Individuals speaking the Irish language in Ireland were seen in the past as backward oriented. The Irish language can, however, be described today as a phenomenon of middle-class culture concerning the Irish-medium schools (gaelscoileanna). Language as a part of culture reflects the perception of the world by its speakers. Language embodies, interprets, and constitutes the world. Language creates a language worldview reflected in the relevant culture on the basis of its own narration, and thus the historical consciousness of the inhabitants of the given states emerges (also through the medium of school history).

As the previous comments show, language may be perceived as a key aspect of cultural and national identity. For Schröder, language creates a fertile ground for the identification of the individual with the community. ${ }^{6}$ Identity expressed through language may be manifested through the means of language communication which anticipates social interaction, maintains interpersonal relationships and creates a feeling of togetherness, solidarity and belonging. In the words of Ripka, a national language plays invaluable part in the preservation and creation of national and cultural identity. ${ }^{7}$

Nowadays, the issue of language and identity is a central issue. One reason may be a negative prognosis of the very possible extinction of the majority of the world's languages in the future. Indeed,

${ }^{5}$ R.F. Murphy, Úvod do kulturní a sociální antropologie, Praha 1997, p. 39.

${ }^{6} \mathrm{~K}$. Schröder et al., What is Europe? Aspects of European Cultural Diversity, London 1995, p. 84.

${ }^{7}$ I. Ripka, Jazyk ako fenomén kultúry, Bratislava 2000, p. 44. 
It is estimated that until 2050 there will be approximately 1,000 living languages in the world. More than $80 \%$ of languages are threatened with extinction. ${ }^{8}$

In connection with the process of preventing the death of languages, we should also be more aware of the possibility of the revitalisation of minority languages. Languages are conceived as a part of the spiritual cultural heritage of mankind, which is perceived by Bitušíková as a fundamental element supporting and enriching cultural identity. ${ }^{9}$ In a similar way, the Irish language is also viewed as one of the key aspects of the cultural and national identity of the Irish. It is a unique phenomenon which could be used very productively in the future in the sphere of cultural tourism. There are many students nowadays studying the Irish language and having very clear ambitions linked to their future employability through the medium of Irish language. This gives any minority language hope for a better future and is a prerequisite to its preservation. For most people, it is a challenge to learn the Irish language and to use it within the family setting. Enthusiasm to make the effort to protect and use the language in daily life is, therefore, needed in order to preserve the language for future generations.

Nowadays we may notice a new relationship between language and identity in the context of post-nationalism. There is a new element present between them, namely globalization, or alternatively, resistance to globalization. In the Irish context we can see this resistance to globalization in terms of consolidated support for the Irish language in different spheres of life.

Although on the one hand, globalising tendencies enrich diversity, on the other hand, they are also catalysts of uniformity and are viewed as a threat to the existence of small or less-dominant cultures or languages. In this case, the encroachment of English in the Gaeltacht and the dominance of English in the sphere of education, economics and politics threaten the local language. ${ }^{10}$ However, there exists another view of globalization as one which is not a counterproductive element for national identities and cultures, which are considered to have a unique and specific

${ }^{8}$ L. Šatava, Etnicita a jazyk, Trnava 2013, p. 38.

${ }^{9}$ A. Bitušíková, Kultúrna a sociálna diverzita na Slovensku. Štúdie, dokumenty, materiály I., Banská Bystrica 2007, p. 45.

${ }^{10} \mathrm{~S}$. Feeney et al., "Measuring Attitudes to National Identity and Nation-Building in Papua New Guinea", Political Science, vol. 64, no. 2 (2012), p. 27. 
place in the mosaic of global identity. Exogenous changes can be then reinterpreted and transformed in the local culture in terms of global and local coexistence.

We view the Irish language as an important marker in the context of Irish cultural identity. Irish Gaelic today performs more a symbolic than an instrumental role. Although official language policy is focused on Irish language revitalisation, the fact is that the perception of the language as a mere symbol prevails among the predominantly Anglophone inhabitants. Despite this, we would like to think that investments put into the Irish language revitalisation can be of benefit in the sphere of cultural identity enhancement. Any effort dedicated to language revitalisation in the context of its original culture and autochthonous language maintenance is, therefore, to be seen as worthwhile.

\section{LANGUAGES AS UNIQUE ELEMENTS OF EUROPEAN DIVERSITY AND CULTURE}

The European Union is a kaleidoscope of languages, nationalities, cultures and local identities united in diversity. It has never desired to create a monolithic culture based on one single expression of identity related to one dominant language. Indeed,

Support of national and local languages can be a successful alternative to western Anglocentrism in order to foster centripetal tendencies to support non-dominant languages. ${ }^{11}$

The maintenance of linguistic diversity is also of crucial importance, considering the fact that approximately 3,000 languages are now spoken around the world, although the precise number is difficult to obtain. Moreover, without any support for regional and minority languages, this heritage could have been lost forever. Several activities were, therefore, undertaken, and documents adopted, in order to foster and support officially the cultivation and preservation of lesser-used languages.

Furthermore, it could seem unenlightened and not in accordance with the main principles of the EU to concentrate on the adoption of only a few

${ }^{11}$ S. Ondrejovič, V. Krupa, My a tí druhí . . ., op. cit., p. 127. 
core European languages as they could then marginalise other languages. Nowadays, the idea of one European language that would fit all occasions is often discussed. Schröder concurrently views the introduction of one uniform language as a Utopian dream because it could bring about the possible end of a Europe "united in diversity". ${ }^{12}$ In his view, the post-Babel world should not be viewed as a failure, but on the contrary, as a huge treasure. Linguistic diversity should be viewed as a benefit to humanity. This is also connected with the idea of nationhood, which will not be lost in the decades to come, but will probably continue to gain importance. Moreover, national languages are considered manifestations of national cultural traditions.

However, it is important to avoid the failures of the past concerning the ideology of Social Darwinism. The main aim of such ideology was to create a homogenous environment and to engage in resettlement policies which repudiated members of minority communities who spoke a language other than a dominant language. Furthermore, today it is viewed as a myth that a single language constitutes a guarantee of peace and mutual understanding. Indeed, such a linguistic programme was carried out in the 19th and 20th centuries by large empires which pursued and realised their aims through the medium of imperial or colonization policies aimed at other countries' subjugation. ${ }^{13}$

According to Grindheim and Lohndal, language as a crucial part of cultural identity does not have to be an obstacle in achieving an evercloser union in Europe. ${ }^{14}$ The EU can be seen as an advocate for individual languages and identities. Linguistic diversity is not only about dominant languages, but also about dialects and other regional and minority languages. According to the "Eurobarometer Survey" (2006), 72\% of European citizens think that all languages should be treated equally, thus favouring both multiculturalism and multilingualism. As Stein Rokkan has remarked, although language is only one of several expressions of identity, it is deemed the most pervasive and an obvious factor of distinctiveness.

${ }^{12} \mathrm{~K}$. Schröder et al., What is Europe? . . ., op. cit., p. 115.

${ }^{13}$ D. Crystal, Language Death, New York 2002, p. 23.

${ }^{14}$ J.E. Grindheim, T. Lohndal, "Lost in Translation? European Integration and Language Diversity", Perspectives on European Politics and Society, vol. 9, no. 4 (2008), p. 459. 


\section{"THE DEATH OF LANGUAGE" - SAVING THE IRISH LANGUAGE}

Language is one of the crucial parts of cultural and national identity. Language enables us to pass on experience which is also vital for future generations. With regard to the linguistic diversity and protection of regional and minority languages, one should pay close attention to the topic of "the death of language" as cited by various authors. According to Crystal, languages may be classified into several groups depending on the number of their speakers and thus their future viability. ${ }^{15}$ They are therefore divided into "viable languages", "viable but small", "endangered languages", "nearly extinct languages" and "extinct languages" (such as the Cornish and Manx languages). Little-used languages can be further divided into "endangered languages with few or no children learning the languages", "seriously endangered, moribund languages and extinct languages".

Although language and culture are inextricably linked together, they should not be equated. Language and culture can both die. The death of one of them can imply the death of the other. They are mutually interconnected and artificial preservation (in museums and other, mainly cultural institutions) cannot substitute for the loss of a living language. This has been the case with Cornish (spoken in Cornwall, situated at the southwestern tip of England) and Manx (spoken on the Isle of Man). The former became extinct in the 19th century and the latter in the 20th century (1891, 1974 respectively). It is very important to stress the fact that both of them have been revived. In the case of Irish, "the death of the language" was almost achieved by the English policy of supplanting the Irish language with English. Indeed, Elizabethan officials in Ireland believed that Gaelic bred sedition.

Later, during the Victorian era, the Irish people and their native language were viewed as backward and "inferior". There were many negative stereotypes of the Irish depicting them as wild, reckless and indolent, and hostility toward them was extended to their language.

Irish language decline was also caused by the Great Famine which struck Ireland in the period between 1845-1849 and caused huge numbers of deaths and mass emigration abroad.

${ }^{15}$ D. Crystal, Language Death, op. cit., p. 54. 
Presently, in contrast to the past, Irish Gaelic, the first official and national language of the Republic of Ireland, is considered to be the supreme embodiment of independent Irish-Celtic culture. However, it is threatened with extinction (belonging to a group of endangered languages) because of the rapid decline in the number of active users. Irish Gaelic, however, as well as other Celtic languages, is supported financially in terms of a broader Celtic heritage enhancement, language and culture being conceived as part and parcel of an ecological approach towards society.

Nowadays, we can observe more efforts to bring minority languages to life. This is also because language is viewed as an important ethno-significant element which constitutes identity. It may be noticed that many dormant elements of national and cultural identity are being reintroduced in this period of ethnic and cultural revitalisation. It is often claimed by various authors that without the Irish language Ireland would not be Ireland, just as without Finnish Finland would not be Finland. This is why the marginalization of autochthonous languages could be considered, from a psychological point of view, as a threat to the quality of national existence. This can then be viewed as a stimulus for national mobilization and agitation for the protection of original (regional, minority, lesser-used) languages.

The national renaissance of the Irish language in the Republic of Ireland has become of crucial importance for the national and cultural identification of the Irish. The Irish language can be perceived as an important element in terms of cultural identity enhancement. This means that the use of the language should be transmitted to all parts of Ireland in order not to be confined only to the western coastal areas collectively known as the Gaeltachtaí.

In the Republic of Ireland there are many significant institutions and organisations which are crucial for Irish language revitalisation and normalization, for instance: Údarás na Gaeltachta (the Gaeltacht Authority), Ealáin na Gaeltachta Teoranta (organisation aimed at promotion of arts in Gaeltacht) Conradh Gaelige (the Gaelic League), Gaillimh le Gaelige (Galway with Irish), the National University of Ireland, Galway (NUIG), Foras na Gaelige (Organisation for Promoting the Irish Language) An Taibhdhearc (the National Irish Language Theatre). Such institutions are of great value in making Irish people more aware of the significance of the Irish language as an invaluable part of their cultural identity and of the history of the Irish nation. This is done through the medium of various activities ranging from 
Irish language courses, cultural events and the organisation of festivals (Seachtain na Gaelige, Fleadh na Gaillimhe, Sean-nós, etc.), the translation of international stage plays into Irish and advisory services offered to all firms and companies that wish to include Irish in their agenda, thereby creating an added value to their business. In this way, all those concerned participate actively in the promotion of Irish language as a unique element, both national and European, as well as part of the world's heritage in the context of distinctive identity creation.

Furthermore, the media also play an important role in minority language maintenance. In the Republic of Ireland there are TV and radio channels called TG4 and Raidió na Gaeltachta respectively which try to make the language more generally popular. Their support is, therefore, crucial in saving the language for future generations.

\section{REVITALISATION AND PROTECTION OF THE IRISH LANGUAGE}

This paper suggests the following recommendations for revitalising the Irish language in the future and thus preventing the possible "death of language". These recommendations might conceivably be applied in the context of other minority, regional or lesser-used languages in the European context.

The first recommendation is connected with the appointment of a Language Commissioner, a very important position or authority which was established in the Republic of Ireland in order to protect the rights of the linguistic minority. It is very important for any minority language to have a language commissioner, who could be described as an ombudsman for the rights of minority-language users.

Another means of revitalising the Irish language could be through the medium of the creation of new Gaeltachtai (Irish-speaking areas or networks) in the urban centres which could be equipped with a range of different Irish-language services (nursery schools, youth clubs, Irish-medium kindergartens, religious services, sports clubs, groups for adults and for pre-school children). The establishment of such services could facilitate, in the long-term, communication through the medium of Irish and enhance the identity of the affected community.

Counselling and advisory services to parents (also carried out by Údarás na Gaeltachta) in the area of Irish-language education seems to 
be another potentially key factor in the intergenerational transmission of language. However, the success of such activities depends hugely on the future implementation of the 20-Year Strategy for the Irish Language 2010-2030. This strategy interacts with support for bilingualism, stressing the positive effects and benefits of education of bilingual children beginning at an early, pre-school age. The dissemination of information about how positive bilingualism, or even multilingualism can be for children is a real necessity and future parents should be made aware of such potential benefits for their children. This could happen in counselling centres for future parents or for young couples who have decided to start a family. Future parents have to be aware of all the possible benefits which raising their children in two languages, namely Irish and English, would bring to them, ranging from the development of cognitive, creative and communication skills to other social and personal competences the child could easily acquire through the medium of such an elaborate and considered upbringing. Awareness about the benefits of bilingualism could also involve prenatal services in hospitals, reminding future mothers that such an upbringing could undoubtedly have a positive long-term impact in broadening the child's future horizons.

Another recommendation involves the creation of a new curriculum which could be divided into two parts, the first one for native - L1 speakers (speakers who view Irish as their first language or mother tongue, the language they were brought up in or which they were introduced to since their birth), while the second would be suitable for L2 speakers (speakers who started learning Irish language at school only). If this is the case in the future, then it will be also necessary to develop new students' and teachers' books for both language categories of students. It could also be beneficial to think about the division of the subject of "Irish" into two subjects: firstly, the Irish language, and secondly, Irish literature or Irish studies. The first subject would be devoted to the development of the main receptive and productive language skills, while the second, optional subject would be selected by those students interested in topics related to Irish literature or Irish studies. However, this could make the Irish language optional and Irish society is highly polarised over the question of making the language optional or compulsory. Although there are certain views that making Irish optional at secondary level would not do any harm to the language, the question remains as to how many students would choose to attend Irish language lessons, if they were not mandatory. All such decisions should 
be discussed openly in public. While it might be a good recommendation to create another subject besides Irish language lessons, the realization of such a step remains a subject for future debate.

As students are potentially transmitters of language, so it is crucial to make them more aware of the importance of Irish language through the medium of different subjects (history, geography, civics, arts) and cultural events, in order that their interest in the Irish language as a unique product and part of their identity may be increased. In this case, constant reminding of how effectively the Irish language could be used even in the sphere of business activities and future employment is necessary. Moreover, it should be stressed that improving one's language skills and using the Irish language really counts, so that it becomes more than a symbolic item of culture.

As far as the minority media are concerned, it is necessary to make a platform for new media which would support the promotion of Irish. The Irish language media which currently ensure Irish language coverage are, as mentioned above, TG4 and Raidió na Gaeltachta. Both of them play a crucial role in making Irish language visible and audible. There is still, however, no Irish language daily newspaper which could effectively promote the language among the public.

Support for bilingualism, or even multilingualism, is important in terms of effective minority language revitalisation in the context of our multicultural and globalised world. In the Republic of Ireland there are many European and non-European residents who give the country an added value shaped by their different cultural and language practices reflected in specific lifestyles and attitudes towards life. This fact could be viewed as an incentive to changing people's opinions towards studying foreign languages. Upon encountering people from different countries we can see that mastering different languages can bring many long-term benefits. Non-Irish nationals speaking several languages can demonstrate that language skills are crucially needed nowadays and monolingualism is not a blessing anymore, if it ever was. Even the trite saying that "the more languages you know, the more human you are" may be worth following. The value of monolingualism as a norm has become shattered nowadays in the context of the linguistic and cultural diversity of the world. Constant reminding people about the benefits of multilingualism may also increase their wish to study languages other than that which is dominant.

As for education, the key point is immersion in the language, beginning with pre-school education and continuing through to tertiary education. 
Generally, it has been shown that students attending gaelscoils (Irish-medium schools situated outside the Gaeltacht) have attained better results than students studying within mainstream schools. It was stressed many times by respondents that innovative forms of teaching can provide an impetus for motivating pupils to study the given language. Furthermore, there is increased pressure put on teachers of Irish to use innovative materials in an extensive way, and to bring more enthusiasm and positive thinking to classroom. Many respondents agreed that an Irish language lesson should be focused more on the development of communication competencies (oral language skills) which could be used in real life situations. In terms of education at mainstream schools, it would help to have another subject taught through the medium of Irish (arts, civics, drama) in order to make the students aware of the enormous value of the Irish language.

The organisation of summer schools was identified as another significant activity, which is part of youth culture. Summer schools support the social and communication skills of students through immersion in the Irish language and participation in different extracurricular activities in which Irish dominates (e.g. sports or other cultural activities done through Irish). For young people, such exposure to the Irish language may make learning the language fun, "cool" and "trendy" which is really crucial for the future transmission of language. Summer schools also help to keep the Gaeltachtaí economically more sustainable.

As far as tertiary education is concerned, more courses could be possible through the medium of Irish in the future. Such a step, however, demands active use of Irish and increased interest in full or partial studies through the medium of Irish. One good sign for this language is that many students take the opportunity to study Irish or Celtic studies at foreign universities in the USA, Canada, Australia and continental Europe. Such study programs organised outside the borders of Ireland can ignite foreign learners' interest in the Irish language. Any external help counts in revitalising the language and keeping it alive for future generations.

Students (future primary and secondary school teachers) will hopefully have the chance to spend an extended period of their study in the Gaeltacht. Such long-term exposure to Irish- language-speaking communities could itself help to sustain the language and make young people aware that studying a language really matters. As the revitalisation of Irish language presupposes the creation of new working posts for new users of the language, then people would see real material benefits based on language 
acquisition. Unless new working posts are created or a number of services effectively provided through the medium of Irish, no demand for such posts or services will arise.

In addition to all these factors, financial support for the Gaeltacht is crucial. The successful implementation of all activities deemed necessary for the sustainability of Gaeltacht regions could also alleviate outflow of young people from areas deprived by unemployment. All in all, in order to retain the strong presence of the young generation in the area, the Gaeltacht's economy must be invested in as the economy and culture are interdependent. In particular, we have in mind the support of small and middlesized businesses and the creative use of the rural environment, with all its natural and historical beauties for which the region is well-known. This could ensure more income for the inhabitants, making the Irish language an asset in the area of cultural tourism. The Irish language is conceived not only as a cultural but also as an economic asset and may be viewed as an added value for any business. It has got the potential to make each business distinctive by introducing it into the everyday agenda, thus enhancing its sustainability. Bilingualism may be another added value, helping to keep the language visible and alive.

\section{CONCLUSION}

It is more than evident that a large number of world languages will be threatened to a greater or lesser extent by extinction in the coming decades. Therefore, the success of specific revitalisation efforts is directly dependent on the particular position of Irish in the value system of the community in which it is used. Furthermore, the question of language selection is clearly multifactorial and also depends on the personal choice of an individual to use the specific language. For the majority of inhabitants residing in Ireland, the Irish language is important as a symbol, while for the minority of active Irish language users it is an element important for identification, performing both a demonstrative and an instrumental function. The usage of any minority, regional or lesser-used language is connected hugely with the material benefits provided to individuals on the basis of minority language acquisition.

The unambiguous relationship between the Irish language and ethnicity is not absolute in the case of Irish. However, the Irish language still 
fulfils the role of significant economic and cultural capital, which is used by different organisations and institutions. We can see that language as a cultural construct generates the potential to create new places of work. In order to make this happen, however, real support and implementation of all the officially-accepted provisions for the revitalisation of the Irish language are crucially needed.

In spite of the fact that total societal bilingualism is not realistically achievable in Irish society, even in the long-term, exposing people to Irish and reminding them of its importance within different spheres of life can create reasonable conditions for the appreciation of Irish culture and history. We have in mind that expressing Ireland's distinctive culture and history through the medium of Irish language could be regarded as a condition for full individual Irish existence.

The Irish language is supported more than any other minority language spoken in the Republic of Ireland. Despite this fact, the very existence of Irish-language-speaking communities is still fragile. The case of Irish language is very peculiar as it is the autochthonous language of Ireland, which was spoken widely until the second half of the 19th century by the majority of the island's inhabitants. We hope that this data will spark interest on the issue of minority language preservation not only in Europe (Scottish Gaelic, Manx, Welsh, Cornish, Breton, Saami, Basque, Catalan, Flemish languages and so on) but also in the worldwide context (the Maori language in New Zealand, the Hawaiian language and others).

The interest in the Irish language can be increased through the medium of different cultural activities aimed at Irish language enhancement. Although in our article we have pointed out just a few of them, there is a multitude of other activities being carried out by different Irish organisations and state departments. We mentioned only Údarás na Gaeltachta, Foras na Gaelige, Gaillimh le Gaelige, NUIG (National University of Ireland in Galway) and DAHG (Department of Arts, Heritage and the Gaeltacht).

According to Šatava,

Those who describe the language revitalization efforts as a mere waste of time for something that counts only for a few hundred or a few thousand people, reduce the human existence to only one aspect. ${ }^{16}$

${ }^{16}$ L. Šatava, Etnicita a jazyk, op. cit., p. 23. 
This assertion reflects well the importance and significance of any minority language in the context of the cultural identity of a particular community. All languages spoken in the world generate immense national cultural wealth and help to make their community distinctive and idiosyncratic. All languages are crucial and invaluable parts of cultural and linguistic diversity, while at the same time they are the unique elements of the spiritual heritage of humankind.

As far as the Irish language is concerned, we have seen that it can be used in real life through the medium of different cultural forms (sean-nós singing, storytelling, Irish language courses, Irish-medium education, etc.) supporting the interconnection of identity, culture and language. We hope that the Irish language will gain more supporters, enthusiasts and genuine Irish speakers in the process of time, in order that it will stay a vivid part of the Irish national and cultural identity.

\section{BIBLIOGRAPHY}

20 Year Strategy for the Irish Language 2010-2030, 2010, http://www.ahg.gov.ie/en/20Year StrategyforthelrishLanguage/Publications/20-Year\%20Strategy\%20-\%20English\%20version.pdf, 10 October 2014.

Biloveský V., "Does Integrating Europe Need Polylingualism and Multiculturalism?”, European Researcher, vol. 42, no. 2-3 (2012), pp. 455-461.

Bitušíková A., Kultúrna a sociálna diverzita na Slovensku. Štúdie, dokumenty, materiály I., Banská Bystrica 2007.

Crystal D., Language Death, New York 2002.

Davis Th.C., "The Irish and their Nation: A Survey of Recent Attitudes", The Global Review of Ethnopolitics, vol. 2, no. 2 (2003), pp. 17-36.

Feeney S. et al., "Measuring Attitudes to National Identity and Nation-Building in Papua New Guinea", Political Science, vol. 64, no. 2 (2012), pp. 121-144.

Gómez-Estern M.B. et al., "Literacy and the Formation of Cultural Identity", Theory and Psychology, vol. 20 (2010), pp. 231-250.

Grindheim J.E., Lohndal T., “Lost in Translation? European Integration and Language Diversity", Perspectives on European Politics and Society, vol. 9, no. 4 (2008), pp. 451-465.

Murphy R.F., Úvod do kulturní a sociální antropologie, Praha 1997.

Ondrejovič S., Krupa V., My a tí druhí v modernej spoločnosti, Bratislava 2009.

Ó Tuama S., The Facts About Irish, Baile Atha Cliath: An Chead Chlo 1964.

Ripka I., Jazyk ako fenomén kultúry, Bratislava 2000.

Schröder K. et al., What is Europe? Aspects of European Cultural Diversity, London 1995.

Šatava L., Etnicita a jazyk, Trnava 2013. 